凹irginiaTech

Financial Stability Rearticulated: Institutional Reform, Post-Crisis Governance, and the New Regulatory Landscape in the United States David Bieri | February 2015

Working Paper No. 16-01

A version of this paper is forthcoming in P. Iglesias-Rodríguez (ed.), Building Responsive and Responsible Financial Regulators in the Aftermath of the Financial Crisis (Cambridge: Intersentia, 2015).

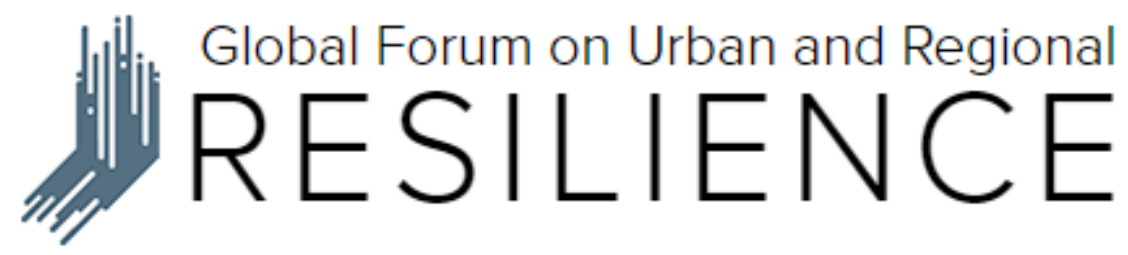

WORKING PAPER 


\title{
Financial Stability Rearticulated: Institutional Reform, Post-Crisis Governance, and the New Regulatory Landscape in the United States*
}

\author{
David S. Bieri ${ }^{\dagger 1,2}$ \\ ${ }^{1}$ Global Forum on Urban \& Regional Resilience, Virginia Tech, Blacksburg, VA 24061, USA \\ ${ }^{2}$ School of Public \& International Affairs, Virginia Tech, Blacksburg, VA24061, US A
}

February 2015

\begin{abstract}
The recent financial crisis was a powerful reminder that the inherent instability of the monetary-financial system is likely to entail serious consequences for the real economy. In the U.S., the monumental Dodd-Frank WallStreet Reform and Consumer Protection Act of 2010 ("Dodd-Frank Act") has provided legislation that aims to institutionalise several aspects a new thinking on financial stability. In addition to the interagency Financial Stability Oversight Council ("FSOC"), the creation of the The Consumer Financial Protection Bureau ("CFPB") marks an important departure from the U.S. regulatory tradition of de-centralized agencies whereby the institutional locus of financial oversight depended on the precise nature of the legal structure of and business activities pursued by individual financial intermediaries. In its mandate and institutional structure, the CFPB unifies both "micro-prudential" and "macroprudential" principles of financial regulation to enhance overall financial stability. From an historical perspective, the creation of the CFPB does not change the regulatory landscape to the same extent as did the creation of the Federal Reserve after the Panic of 1907 or the creation of the FDIC after the 1933 Banking Crisis. At the same time, however, the CFPB represents an important historical shift in the policy focus of U.S. financial regulation away from bank stability bank to a broad notion of financial stability that recognises the increased financialisation of households' welfare.

Keywords: Financial stability, CFPB, financial regulation, regulatory accountability, financialization.

JEL classification: E5, E42, G18, G28, B52.
\end{abstract}

* Chapter prepared for Building Responsive and Responsible Regulators in the Aftermath of the Financial Crisis, P. Iglesias Rodrígues (ed.), forthcoming, Cambridge, UK: Intersentia.

${ }^{\dagger}$ Corresponding author: GlobalForum on Urban \& Regional Resilience, Virginia Tech, 250S. MainSt. (Suite 312), Blacksburg, VA24601-0922, USA. Web: ci rcu1ar-flows . org. Email: bi eri@vt . edu (David Bieri) 


\section{Introduction}

Therecent financial crisis was a formidable reminder of theinherentinstability of the monetaryfinancial system and of the serious consequences for the real economy that this instability entails. ${ }^{1}$ This chapter argues that the broad range of policy responses to the crisis in the UnitedStatesare unified bya common theme,namely a shift in the policystance away from monetary stability towards financial stability. On the one hand, this shift is characterised by an extension of the perimeter of financial regulation such that it puts the monitoring of systemic risk on an institutional footing. On the other hand, the U.S. regulatory stance has tilted away from traditional concerns over bank stability towards an institutional recognition that household decision making is increasingly financialised.

The monumental Dodd-Frank Wall Street Reform and Consumer Protection Act of 2010 ("Dodd-FrankAct") has provided legislation that aims to institutionalise several aspects that are emblematic of this new thinking on financial stability. In addition to the interagency Financial Stability Oversight Council ("FSOC"), the creation of the Consumer Financial Protection Bureau ("CFPB", "Bureau") marks an important departure from the U.S. regulatory tradition of de-centralized agencies whereby theinstitutionallocus offinancialoversight depended on the precise nature of the legal structure of and business activities pursued by individual financial intermediaries. An independent regulatory agency of the United States government, the Bureaus's mandate is to make "consumer financial products and services work for Americans". Its purview thus ranges from financial literacy education to financial regulation which includes banks, credit unions, securities firms, payday lenders, mortgageservicing operations, foreclosure relief services, debt collectors and other financial companies operating in the United States. Despite its outwards appearance as a single-purpose regulator, the CFPB's mandate and institutional stucture unifies both "micro-prudential" and "macroprudential" principles of financial regulation to enhance overall financial stability.

The remainder of this chapter is structured as follows. The next section discusses the scope and limits of financial regulation, focussing on the shift from monetary stability to financial stability as an emergent policy paradigm in more recent years. In section 3, Iexamine the institutional arrangements and governance challenges of the U.S. regulatory and supervisory complex. I also investigate possible consequences of some of the shortcomings and compromises that have plagued recent regulatory reform. The CFPB as an institutional response to the crisis is explored in more detail in section 4 . This section also highlights that the post-crisis U.S. regulatory landscape is defined by a historical shift in the policy focus away from bank stability to a broad notion of financial stability that recognises the increased importance of finance for households welfare. Thesenewinstitutional realities maintain pose very specific challenges for regulatory and supervisory accountability. Section 5 offers some concluding thoughts on the post-crisis regulatory landscape.

\section{The quest for financial stability}

In contrast to monetary stability, there is a much broader spectrum of definitions and consensus only seems to exist in so far as financial stability is deemed a "good thing" and that

\footnotetext{
${ }^{1}$ I use the term "monetary-financial system" in keeping with Chandler's (1979) view that monetary institutions and financial financial markets now overlap to such a degree that they are best viewed as parts of a larger whole.
} 
it is mostly noticed by its absence. ${ }^{2}$ One of the earliest definitions of financial stability is given by Bagehot (1873) who describes financial stability as "[...] not a situation when the Bank of England is the only institution in which people haveconfidence." Despitemuch definitional progress in the century and a half since Bagehot, a firm consensus for financial stability has yet to emerge, albeit not for a shortage of efforts. The recent financial crisis has led to a veritable outpour of policy work, white papers and theoretical treaties, all attempting to pin down this elusive concept further. ${ }^{3}$ The question remains whether financial stability requiresjust the soundness of institutions, the stability of markets, the absence of turbulence, low volatility, or whether it constitutes something more fundamental (Schinasi, 2004).

Broadly speaking, one can distinguish between a systems approach - primarily linking financial stability to a well-functioning financial system - and a morenarrow definition relating to the (excess) volatility of an observable financial variable, such as asset price volatility or interestrate smoothness. The debate around finding a suitable definition is more than a semantic one, particularly since any given definition predeterminestheroleassigned tospecific institutions in contributing to financial stability (Bieri, 2010).

Fromanhistorical perspective, one can broadly outlinea typology of financial market upheaval that distinguishes between three types of financial instability. First, there is volatilitybased instability, such as the crises of the European Exchange Rate Mechanism in the 1980s and 1990s, the 1987 stock market crash, the 1994 emerging market bond market instability, the1998 Russian default, the Argentinean default in 2001 and mostrecently, the US subprime crisis in 2007-08. A second type of instability is stress-based instability, which is often triggered by the default of an individualfinancialinstitution. Instances of stress-based instability include the insolvency of Credit-Anstalt in 1931, the collapse of Bankhaus Herstatt in 1974, the folding of the Bank of Credit and Commerce International in 1991, the Barings scandal in 1995, the failure of Long-Term Capital Management in 1998 and the most recent string of institutional failures, from Northern Rock to Bear Stearns, Lehman Brothers and the American International Group. Lastly, there are instances of crisis-based financial instability that are largely characterized by a triggering development that originates in the real economy or the financial system. Costly bank insolvencies and major adjustments in the level of asset prices tend to follow. During this type of financial instability, there is often a very strong (reinforcing) interaction between the financial sector and the real economy, with strong contagion effects both domestically and internationally. Aside from the Great Depression, the Scandinavian banking crisis in the late 1980s, the bursting of the Japanese asset bubble in the 1990s, the Mexican crisis (1994-95) and the Asian financial crisis all fall into this class of crises.

While no episode of financial upheaval neatly fits into any one of the three categories, a classification can be informative for policy purposes. The recent financial crisis is an important case in point; what started as distant volatility rumblings of market-based financial instability in the U.S. sub-primemarketin mid-2007eventually snowballed into afully blown global crisis with major financial instability across several marketand institutional segments, including upheavals in the government debt market in Europe.

From the perspective of policy makers, however, it is clear that some of the elements that

\footnotetext{
${ }^{2}$ Consensus with regard to the definition of monetary stability has emerged during much of the $20^{\text {th }}$ century and permits various notions ranging from stability of the (anticipated) value of money to price-level stability or even low levels of inflation.

${ }^{3}$ The literature is far too voluminous to do full justice here, but some important milestones in the development a cohesive body of knowledge in this area include Bordo and Wheelock (1998); White (2008); Borio and Drehmann (2009); Mayes, Pringle, and Taylor (2009); Krainer (2012, 2013).
} 
might potentially harbour a threat to financial stability are actually very desirable for achieving the goal of monetary stability. Financial innovation, for example, has been key to making thetransmission mechanism for monetary policy moreeffective. Thisapparent tension raises the question of a latent trade-off between monetary and financial stability with important implications for regulatory accountability that I discuss in more detail in section $4 .{ }^{4}$ Despite the increasing interlinkages of globalized financial markets, the implementation of policy goals pertaining to both monetary and financial stability still rests almost exclusively with national institutions. The recent financial crisis was a forceful reminder of the increasing difficulties to obtain these objectives without coordinated efforts at the supranational level. The next section takes a closer look at the institutional division of labor for financial stability in the United States.

\section{The institutional arrangements of U.S. financial reg- ulation}

Historically, the main policy focus of the U.S. financial regulatory system has been one of "prudence" (Calomiris and Gorton, 1991; Calomiris, 2000). Beginning with the National Banking Acts of 1863 and 1864, the institutional emphasis of U.S. regulation has been placed on the twin objectives of bank stability and monetary policy. Most major regulatory reforms and institutional innovations of the U.S. regulatory landscape of the last 150 years followed in the wake of a financial crisis, either strengthening systemic bank stability or the implementation of monetary policy. Indeed, the creation of the Federal Reserve System in 1913 a response to the Panic of 1907 - and the creation of the Federal Deposit Insurance Corporation ("FDIC") after the 1933 Banking Crash mark the most important events in this regard. While the creation of the CFPB perhaps does not change the regulatory landscape to the same extent as did the creation of the Federal Reserve and theFDIC, it represents an important shift in the policy focus of U.S. financial regulation away from bank stability and monetary policy to consumer protection.

\subsection{Micro-prudential entities}

In characterising regulatory functions at the micro-prudential scale (i.e. focusing on individual types of financial institutions, functions or markets), it may be useful to distinguish between regulators that generally focus on prudence and regulators that generally focus on disclosure. Prudential regulationimplies themonitoring and regulation of risks that aspecific firm engages in, whereas regulatory disclosure monitors and regulates the information that firms and exchanges provide to potential market participants. Figure 1 provides an overview of the institutional arrangements of the U.S. regulatory context in this regard. Four federal agencies have prudential authority to regulate and supervise banks, thrifts, and creditunions (i.e. the Office of the Comptroller of the Currency, "OCC"; the FDIC; the National Credit Union Administration, "NCUA"; and the Federal Reserve). In addition to prudential regulators with an institutional focus, there are three prudential agencies with an activities-based mandate, regulating the farm credit system (Farm Credit Agency "FCA"), the federal housing finance system via the Federal Housing Finance Authority ( "FHFA" monitoring government sponsored entities, "GSEs") and consumer financial products (CFPB), respectively.

\footnotetext{
${ }^{4}$ See also Bieri (2008) for a more detailed discussion of this point.
} 
Figure 1: The institutional arrangements of U.S. financial regulation

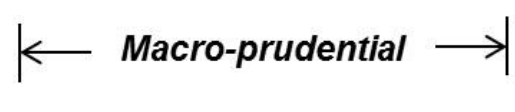

Systemic risk

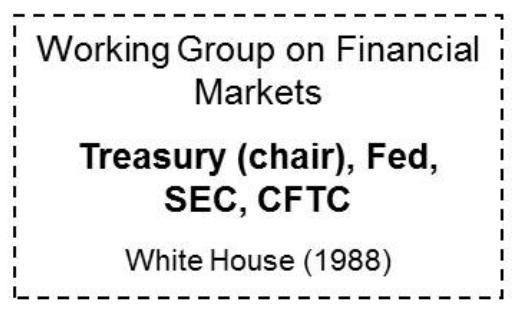

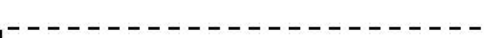

Financial Stability Oversight

Council

Treasury (chair), Fed,

OCC, FHFA, CFPB, FDIC, NCUA,SEC, CFTC

rnment organisation

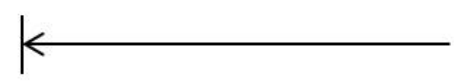

Institutions

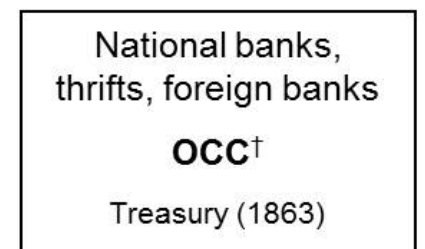

\begin{tabular}{c}
\hline Deposit insurance \\
FDIC* $^{*}$ \\
Federal agency (1933)
\end{tabular}
(2011)

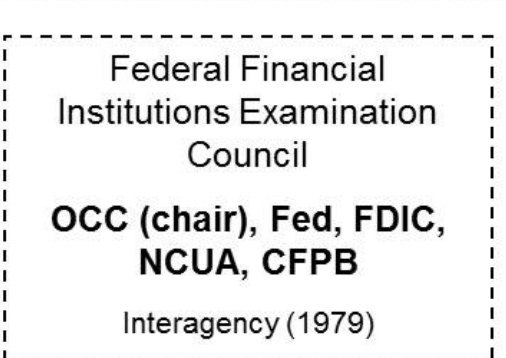

Interagency (1979)
Federal credit unions
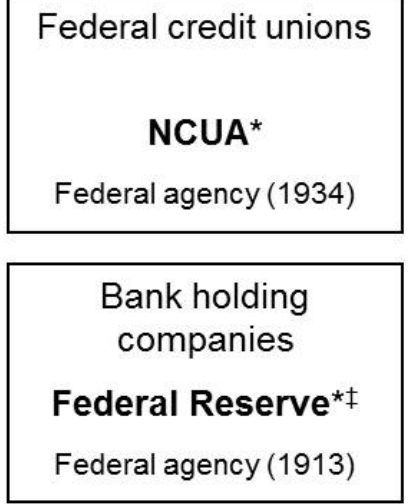

Micro-prudential

Activities

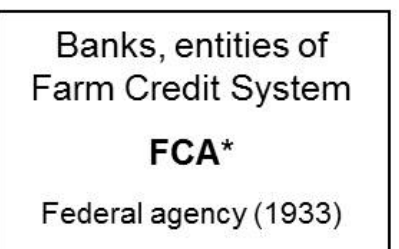

Federal agency (1933)

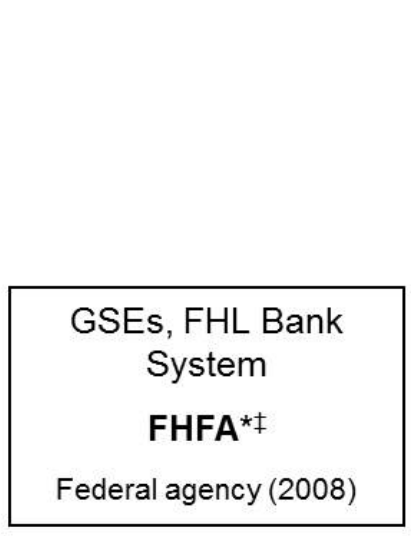

Consumer finance
CFPB $^{* \ddagger}$
Federal agency $(2011)$
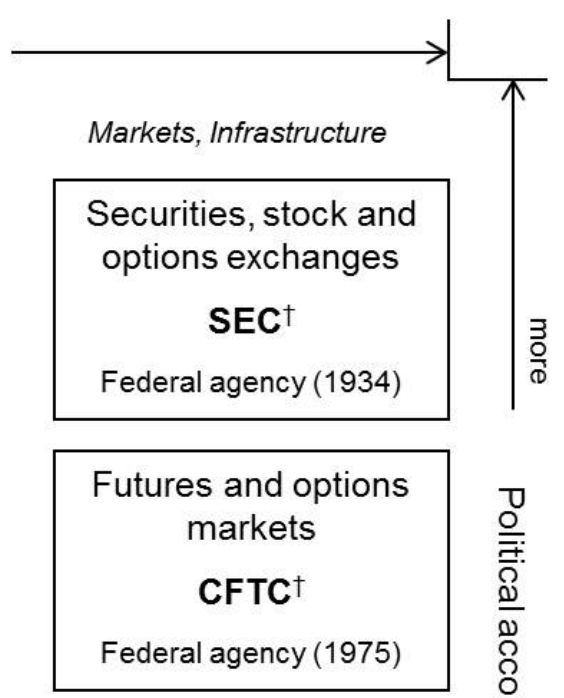

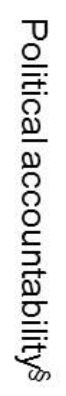

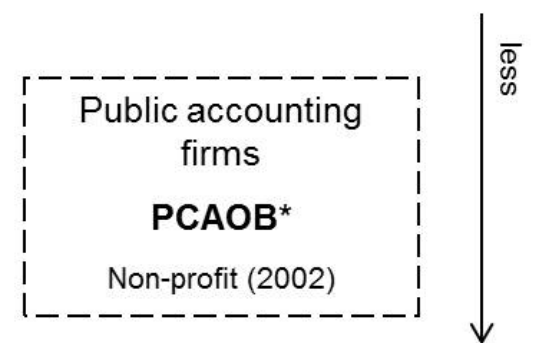

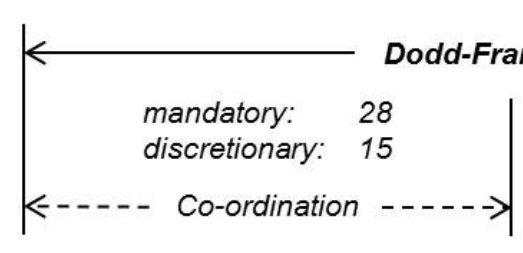
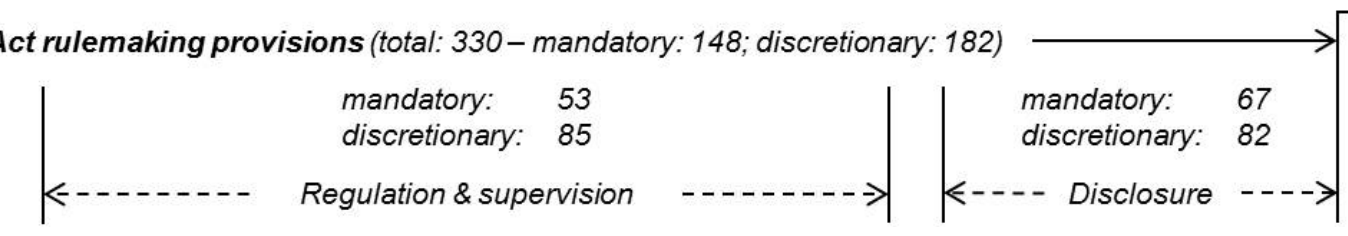

Source: Author. Notes: * Independent federal agency with self-funding. Funding source is not only independent of Congress, but authority to use funds is not conditioned on congressional budgetary approval. ${ }^{\dagger}$ Independent federal agency without self-funding. Accountability via budgetary appropriations process. ${ }^{\ddagger}$ "For-cause” removal protection of director, commonly used to distinguish between independent and executive branch agencies. ${ }^{\S}$ Degree of political accountability is determined using a number of criteria, including the degree of self-funding, for-cause protection of the director, multi-member boards and the requirement for partisan balance on the board. 
Among the disclosure-based regulators, two agencies oversee markets for financial contracts such as securities and derivatives (i.e. the Securities and Exchange Commission, "SEC" and the Commodities Futures and Trade Commission, "CFTC").

The policy problems and regulatory approaches of the agencies listed infigure 1 vary considerably. For example, the prudential bank regulators and the FHFA examine firms with specific charters and monitor and limit the risks that their chartered firms engage in. Securities and derivatives regulators monitor exchanges that host the trading of financial contracts, oversee the disclosures that market participants provide, and enforce rules against deceptive or manipulative trading practices. Unlike prudential bank regulators, securities regulators generally do not monitor the composition of assets and liabilities of the firms participating in their markets. ${ }^{5}$ These and other general differences may exist because of the various missions and risks to financial stability that the agencies each address individually.

\subsection{Macro-prudential framework}

At the macro-prudential scale, there are three entities with an institutional mandate to act as an interagency coordinating forum. These entities are made up of the micro-prudential financial regulators with related duties or functions and facilitate communication and coordination among member agencies. In each instance, the creation of a coordinating entity is a policy response to an episode of systemic financial instability. The Federal Financial Institutions Examination Council ("FFIEC") was a response to a spike in bank failures ${ }^{6}$ during the early 1970s, the President's Working Group on Financial Markets ("WGFM") a reaction to the stock marketcrash of 1987, and, most recently, the FSOC a reply to the recentfinancial crisis. While not tasked to address systemic risk in the same comprehensive manner as the FSOC, both the FFIEC and the WGFM are thus important institutional precursors to an emergent thinking about macro-prudential regulation that is now fully embodied in the FSOC.

Indeed, former U.S. Treasury secretary Tim Geithner's (2014) memoirs document that the fragmentation of the U.S. financial system's main regulatory agencies encumbered coordination during the recent crisis as agencies appeared to lock horns over divergent political interests. As such, the Dodd-Frank Act may have failed to fix the fractured and fractious regulatory system of the United States. Indeed, one the Act's many imperfections is that the responsibility for monitoring systemic risk was lodged not inside the Federal Reserve, the one agency that had to pick up the pieces of a financial crisis, but with the FSOC which is made up of all thosefeuding agencies.

A distinguishing feature of the U.S. regulatory landscape is that - despite the existence of single-purpose regulators, such as the CFPB - the regulatory activities of individual agencies are not necessarily mutually exclusive. The creation of the CFPB also marks a departure from the U.S. regulatory tradition of de-centralized agencies whereby the institutional locus of financial oversight has long depended on the precise nature of the legal structure of and business activities pursued by individualfinancial intermediaries. For deposit-taking

\footnotetext{
${ }^{5}$ Although the distinction between prudence-based regulators and disclosure-based regulators may be true in general, bank regulators can regulate the disclosures of their chartered firms and securities and derivatives regulators do have some prudential responsibilities. See Jickling and Murphy (2010) and Murphy (2013) for more details on this point.

${ }^{6}$ The FFIEC was established in 1979, pursuant to TitleX of the Financial Institutions Regulatory and Interest Rate Control Act of 1978 (FIRA) to curtail bank failures by regulating the banking industry more closely. See Garrison (1987) for more details.
} 
institutions, for example, this means that that the Federal Reserve regulates bank holding companies, whereas national banks, state commercial and savings banks are supervised by the National BankSupervisors, state bank supervisors and the FDIC, respectively. Similarly, federally chartered credit unions are regulated by the National CreditUnion Administration, while state-chartered credit unions are regulated at the statelevel. ${ }^{7}$

In light of the fact that the post-crisis U.S. regulatory landscape is defined by a historical shift away from bank stability to a broad notion of financial stability that recognises the increased importance of finance for households welfare, the next section now focuses on the $\mathrm{CFPB}$ as an institutional response to the crisis in more detail.

\section{The CFPB as a post-crisis response}

The CFPB is an independent regulatory agency of the United States government with a mandate to make "consumer financial products and services work for Americans". Its purview ranges from financial literacy education to financial regulation which includes banks, credit unions, securities firms, payday lenders, mortgage-servicing operations, foreclosure relief services, debt collectors and other financial companies operating in the United States. In important ways, the creation of the CFPB recognises that the structural transformation of the financial system, characterised by technological change, financial innovation, and financial deregulation, has meant that an increasingly large component of the financial decision making that affects household welfare has been delegated to individual households themselves.

From managing their own pensions to taking important credit decisions to finance housing and other large-ticket consumption expenditures, the institutional center of gravity for financial decisionmakingnolonger resides with financial professional, but with thecommon household. This democratisation of access to credit and thelarger participation of individual households in financial market activity have extended the policy boundary of the monetaryfinancial system. The financialisation of household decision making implies that concerns about financial stability no longer automatically just extend to concerns about the solvency and liquidity of banking institutions, but also extend to the financial stability of individual households. ${ }^{8}$ Politically, thus, the creation of the CFPB was driven by a narrative of the crisis as one where consumer abuse in the financial sector was rampant as scrupulous financial predators took advantage of the financial needs of households, particularly of low-income and minority families (e.g. Barr, 2012). ${ }^{9}$

Legislation for the creation of the CFPB was authorized by the Dodd-Frank Wall Street Reform and Consumer Protection Act, the passage of which in 2010 was the most important regulatory response in the United States to the financial crisis of 2007-2008. The Bureau was formally established when Dodd-Frank was enacted, onJuly 21,2010. After a one year "stand up" period, the Bureau obtained enforcement authority and began most activities on July 21, 2011. The creation of the CFPB marks perhaps the most significant change to the post-crisis

\footnotetext{
${ }^{7}$ See Barth, Liy, and Luy (2010) for more details on the historical evolution of U.S. banking regulation.

${ }^{8}$ Lusardi and Mitchell (2014) provide an overview of why financial literacy matters more for financial stability than ever.

${ }^{9}$ At the same time, however, an equally plausible narrative is that of declining lending and underwriting standards across important segments in the credit markets in the run up to the crisis, suggesting that lenders' screening decisions, first and foremost in the subprime market for low-documentation loans, were becoming more lax during the upswing of the credit cycle (Mayer, Pence, and Sherlund, 2009; Anderson, Capozza, and van Order, 2011; Keys, Seru, and Vig,2012).
} 
regulatory institutional landscape in the United States.

\subsection{Institutional focus and policy mandate}

In consolidating in one place responsibilities that had been scattered across various government agencies, the CFPB is intended to increase government accountability, while at the same time having additional responsibility for supervision and enforcement with respect to thelaws over providers of consumer financial products and services that previously escaped regularFederaloversight. Primarily, however, the Bureau isintended to protectfamilies from unfair, deceptive, and abusive financial practices. Focusing both on the demand side and on the supply side of financial services, the CFPB is intended to make regulations and issue guidance as clear and streamlined as possible, so providers of consumer financial products and services can follow the rules on their own.

Designed to overcome the historical fragmentation of the U.S. regulatory complex, the CFPB thus consolidates employees and responsibilities from a number of other federal regulatory bodies, including the Federal Reserve, the Federal Trade Commission, the FDIC, the NCUA, and even the Department of Housing and Urban Development. Technically, the CFPB is an independent unit located inside and funded by the Federal Reserve, with an interim affiliation with the U.S. Treasury Department.

Specifically, the CFPB's areas of activity can broadly be categorized into "supervision, regulatory compliance and enforcement" and "financial research and education". In the first category, the Bureau's activities are comprised of (i) rule making, supervision and enforcement offederal consumer financial protection laws; (ii) enforcement of financial antidiscrimination legislation and other unfair treatment in consumer finance; and (iii) restriction of unfair, deceptive, or abusive acts or practices. At present, CFPB's most pressing concerns are mortgages, credit cards and student loans. In the second category, the CFPB focuses on (i) collection of consumer complaints; (ii) strengthening of financial education; (iii) research on consumer behavior; and, (iv) monitoring of financial markets for new risks to consumers.

Indeed, much of the Bureau's policy remit and scopeare directly reflected in its organizational structure which is separated into six divisions: (i) Supervision, Enforcement, and Fair Lending; (ii) Research, Markets, and Regulations; (iii) Office of the Chief Operating Officer; (iv) General Counsel; (v) Consumer Education and Engagement; and (vi) External Affairs. In terms of regulatory governance, the CFPB breaksimportant new grounds in that it relies on legal enforcement, rather than the traditional process of supervision that permits regulatory fine-tuning as part of ensuring compliance. While bank supervision is principally a forward looking process that resolves problems informally without sanctions for past violations, enforcements requires formal federal legal action. In contrast to her colleagues at other regulatory agencies, the CFPB examiner's influence and effectiveness thus depends on the agency's "willingness to make a federal case out of financial misconduct" (Beales, 2012).

In its mandate and institutional structure, the CFPB unifies both micro-prudential and macro-prudential principles of financial regulation to enhance overall financial stability. Beyond protecting borrowers and investors that participate in financial markets, the CFPB contributes to achieving financial stability by minimizing possible disruptions to the broader economy that might emanate from the financial sector. 


\subsection{Financial stability as a public good}

The rationale for financial regulation such as that contained in the CFPB's mandate ultimately rests on two objectives: (i) the desire to maintain financial stability by mitigating systemic risk, and (ii) the desire to protect consumers (investors). Consumer protection and mitigation of systemic risk are mostly complementary, but they can also conflict. The recent crisis has shown that measures taken to protect particular market participants (e.g. home owners in the U.S. or depositors in the Eurozone) may sometimes have unintended consequences, whichare increasing systemic risk.

Indeed, financial stability carries all the textbook hallmarks of a public good. First, it is non-rival as its benefits to one consumer are not limited by the simultaneous consumption by other consumers. Second, financial stability is non-excludable as its benefits are available to all economic agents, even to those who do not pay for it (i.e. entities that are not regulated, such as, e.g. shadow banks and other non-depository financial intermediaries). Lastly, individual agents cannot actively withdraw themselves from theinfluence of financialstability.

Public finance theory has long established that the private-sector production of public goods yields an under-supply with respect to its optimal quantity. For this very reason, financial stability has traditionally been produced by and provided by national governments. Globalization, however, has brought about a partial shift in the optimal locus of production, since financial stability is no longer a fully spatially delineated public good. Indeed, the importance of international public goods such as financial stability or an international regulatory level playing field, has considerably raised the stakes in the ordo-liberal challenge for well-coordinated international policy co-operation in the age of turbulence.

The economic theory of regulation pioneered by Stigler (1971) stipulates that regulation often induces changes in behavior which go against the very effects that regulation intended in thefirst place. During period sof investor exuberance and comparative regulatory complacency, theseadverseeffects of regulation are very likely to bemuted if not invisiblealtogether. Any new regulation-from DoddFrankat thelocal level to BaselIII(BCBS,2013), the most recent international regulatory framework for banks, at the global level - will bring with it the so-called boundary problem of regulation, i.e. the problem that institutions in the regulated sector and those in the unregulated sector face different incentives. Supervisors must thus attempt tolearn how the regulated are seeking to avoid the constraints placed upon them (Goodhart, 2008).

During the Great Moderation, the boundary problem profoundly misaligned incentives across many agents in the financial sector as systemic financial imbalances accumulated in the run-up to the crisis. This induced large-scale regulatory capital arbitrage, e.g. in the form of securitization, which offset some or all of the intended regulatory effects. Regulation failed to take account of the risks that can emerge from the interaction between regulated and unregulated institutions, activities, and markets. In particular, bank regulation did not reflect risks from off-balance-sheet vehicles, monoline insurance companies, shadow banks or loanoriginators with weakunderwriting standards. Equipped with the analysisfrom ratings agencies, even sophisticated investors could not be relied on to assess risk accurately on more complex financial products.

To be sure, it can be argued that is was the principal-agent problems in the public sector thatenabled many of the principal-agent problems in the private sector that are so commonly blamed for the crisis. One of the immediate legacies of the crisis is a massive series of bailouts by public authorities in Europe and the United States that, according to work by Herring (2010), amounted to the equivalent of nearly one-fifth of world GDP in taxpayer funds. In 
turn, the sheer magnitude of the bailouts has created a new moral hazard in that it might lead to deeper and more frequent crises unless counteracted by more "regulatory bite".

\subsection{Regulatory governance and the accountability challenge}

Despite the fact that the global financial system is increasingly interlinked, much of the international regulatory system still operates on a sectorallevel. Indeed, as the financiallandscape of the post-Bretton Woods era has changed, and banks, insurers, and securities firms have begun to offer similar or even identical products, central banks and regulatory authorities such as the CFPB have recognized the growing need for a central vehicle for coordinating their efforts. At the level of the global financial system, the various regulatory and supervisory initiatives of the Basel-based committees and their working groups form the core institutional building blocks of such a global coordination exercise. This global framework which is aimed at harmonizing regulatory and supervisory processes and standards is collectively known as the "Basel Process" (Bieri, 2009).

Global governance Among the plethora of regulatory efforts that address the new realities of financial globalisation, the Basel Process is uniquely positioned to provide policy makers with an institutional arrangement for regulatory coordination, governance and standard setting. The Bank for International Settlements ("BIS"), the world's oldest and perhaps least well-known international financial institution, provides the locational anchor for the Basel Process which has come to form the natural home for the global policy coordination among central bankers and regulators. ${ }^{10}$ As the political geography of the world is still more or less organized around the building block of the nation state, central banks and other institutions involved in the Basel Process are inevitably going to be held accountable by the citizens of their nation states, even if their nature is not directly susceptible to democratic pressure. ${ }^{11}$ The institutional responsibilities for financial stability are traditionally shared across different institutions, namely finance ministries, the central bank and regulators. While clearly defined accountabilities for each of the institutions involved is a sine qua non, the actual goal of financial stability can only be brought about by an effective coordination of these efforts. Thisis the role of theBaselProcess.

While BIS and its central bank members have engaged in several initiatives to improve thetransparency of decision-making processes, the Basel Process mightnotalways beconsidered "accountable" in the ways citizens might want. For example, Kane (2007a,b) argues that participants in the BCBS process lacked sufficient democratic accountability to reconcile the fundamental conflicts between bank, regulator and societal interests that arise in efforts to connect national safety nets. Referring to "gaps in the cross-country regulatory contract", he explains how national differences in regulatory accountability made gaps in the cross-country deal more easily tolerated in other BCBS countries than in the USA. More prominently, the "Lamfalussy Process" on pan-European financial services legislation has incurred considerable public criticism as it allows some elements of bypassing accountable oversight by the Council of the European Union and the elected European Parliament. ${ }^{12}$ This echoes similar concerns by Robinson (2002) who argues that the international framework for governing

\footnotetext{
${ }^{10}$ Perhaps one of the most prominent recent initiatives arising out of this process is the most recent incarnation of the international regulatory framework for banks, commonly referred to as Basel III.

${ }^{11}$ The 2006 Global Accountability Report assigns a relatively low "accountability score" to the BIS in comparison to other international institutions (Blagescu and Lloyd, 2006).

${ }^{12}$ The Lamfalussy Process was created in 2001 in order to enhance flexibility for European securities legislation
} 
globalizationlacksaccountability and is undemocratic, thus largely embodying a moveaway from representative, participatory democracy towards a state of technocratic governance.

Despitethefact that financial globalization has created rising interdependencies between institutions, markets and infrastructure and the co-operative efforts of the Basel Process in response, there remains a good deal of local and sectoral fragmentation in the international regulatory system. Official definitions of systemic risk leave out the role of government officials in generating it. To underscore and strengthen regulators' duty of accountability, Kane (2010) calls for a series of informational reforms designed to measure systemic risk on an ongoing and less conflicted basis. This program has three components: (1) expanding the types of information financial institutions generate and report; (2) separating bureaucratic responsibility for measuring growth in the safety net from responsibility for limiting safetynet growth; and (3) improving the tools and incentives of safety-net managers. ${ }^{13}$

National accountability At the national level, the complex and multi-faceted interaction between accountability and governance issues in the U.S. regulatory system are evidenced by the fact that the Dodd-Frank legislation contains well over 300 explicit provisions that at least permit or require rule making. The bottom panel of figure 1 highlights how these rulemaking provisions are distributed across macro- and microprudential considerations for financial stability. Indeed, five years into the adoption of the legislation, it is still not clear in fact technically unknowable - how many rules will ultimately be issues pursuant to the act, because most of the provisions are discretionary and agencies may or may not issue to rule, individual provisions might result in multiple rules, and some provisions provide rulemaking authority toagencies that technically already possess such authorities (Copeland, 2010). ${ }^{14}$

Since passage of the Dodd-Frank Act, its initial 848 pages of statutory text have ballooned to more than 14,000 pages - testimony to an unimaginable explosion of administrative complexity compared to, for example, the decidedly anemic 37 pages of 1934 Glass-Steagall Act (Kane, 2012). Furthermore, over $80 \%$ of the provisions assigned rulemaking responsibilities or authorities to one of five federal agencies: the Federal Reserve, the FDIC, the SEC, the CFTC, and the newly-created CFPB. Dozens of other provisions in the act gavejointrulemaking responsibility or authority to two or more of these agencies.

In quantifying the extent of political accountability of an independent agency in the U.S. regulatory complex, one of the most agreed upon characteristics is what is termed "for cause" removal protection, which is intended to provide a measure of independence from presidential direction and control. ${ }^{15}$ The political fight over the CFPB's structure was largely focused

by reacting promptly to market developments and benefitting from expertise of national supervisory authorities. As part of this process, the EU institutions agreed to accelerate the passage of financial services legislation and began applying to securities legislation in 2002 and to banking legislation in 2004 (Alford, 2006).

${ }^{13}$ See also Volker and Ferguson (2008) for a discussion of key organisational challenges for the design of global governance of financial regulation and supervision.

${ }^{14}$ Washington Law Firm Davis Polk monitors monthly progress in the Dodd-Fank implementation using its Regulatory Tracker. By the end of 2014, a total of 280 Dodd-Frank rulemaking requirement deadlines have passed. This is over $70 \%$ of the 350 some total rulemaking requirements, and $100 \%$ of the 280 rulemaking requirements with specified deadlines. Of the total rulemaking requirements, $230(58 \%)$ have been met with finalized rules and rules have been proposed that would meet $94(26 \%)$ more. Rules have not yet been proposed to meet $96(26 \%)$ rulemaking requirements.

${ }^{15}$ The heads of Cabinet departments and independent agencies generally serve "at the pleasure of the President" and therefore can be removed at any time. In contrast, the heads of independent regulatory agencies, whether part of a multi-member board like the SEC or a single administrator like the CFPB, can only be removed by the President 
on the Bureau's for-cause-protected, single-member head, which Congress combined with the Bureau's exclusion from the congressional appropriations process, because it was believed thatself-funding would beessential to theCFPB'sindependence(Beales,2012). Indeed, while self-funded agencies are a rarity in U.S. administrative law, their freedom from both congressional budgetary approval and the congressional appropriations process gives self-funded agencies potentially a unique degree of political independence (Kruly, 2013). ${ }^{16}$ The CFPB's unique structure thus gives the Bureau independence from direct Executive oversight in at least three ways: (1) the Bureau is headed by a for-cause protected director; (2) it has independent litigation authority; and (3) it is permitted to officially communicate with Congress without first obtaining approval from the Office of Management and Budget.

Indeed, figure 1 shows that the CFPB is at the very low end of the spectrum in terms of its degree of political accountability, even when measured - in addition to the for-cause protection of the director - using a much wider number of criteria, including the degree of self-funding, multi-member boards and the requirement for partisan balance on the board. Given this sizeable broadening of the post-crisis mandate of U.S. financial regulatory agencies, concerns have not only arisen in terms of regulatory accountability, but also in terms of the (unintended) economic burden that new regulatory legislation mightentail. Infact, a number of individuals and organizations have recommended that independent regulatory agencies be required to prepare economic cost-benefit analysis before issuing certain rules (Copeland, 2013). A common argument for the introduction such analysis is that it would bring muchneeded transparency and accountability to the rule-writing process in the U.S. regulatory complex. ${ }^{17}$

Overall then, the creation of the CFPB tilts the post-crisis regulatory institutional landscape in the United States towards more regulatory independence in significant ways. As figure 1 illustrates, the Bureau's strong budgetary independenceand relativeinsulation from political processes is on par, if not higher than that of the Federal Reserve and the FHFA, raising new challenges of accountability and regulatory governance.

\section{Regulatory lessons from the recent financial crisis}

In very broad terms - as the global economy no longer stares into the abyss of a financial market fallout and the first green shoots of an tentative recovery are visible - the principal regulatory lessonis twofold. First, at a micro-prudential level, theregulatory perimeter needs to be strengthened and extended. It was excessive risk taking by global financial actors outside this very perimeter that lies at the origin of current crisis. Going forward, this implies

\footnotetext{
for some type of "cause" (Copeland, 2013).

${ }^{16}$ In line with the literature, I use the term "self-funded" to describe an agency whose funding source is not only independent of Congress, but whose authority to use those funds is not conditioned on congressional budgetary approval. Congress has empowered a number of agencies to collect fees and fines that the agencies then use to fund their operations. However, not all form of self-funding provides the same degree of political independence. The Federal Communications Commission ("FCC"), for example, is self-funded in the sense that it funds its operations from the fees it collects. At the same time, the FCC may only collect and use fees in an amount authorized by Congress. In contrast, the Fed is simply authorized to "levy semiannually upon the Federal reserve banks... an assessment sufficient to pay its estimated expenses and the salaries of its members and employees." See Kruly (2013) for a more detailed discussion of this point.

${ }^{17}$ For example, the American Enterprise Institute, a conservative think tank, proposes a statutory requirement for economic analysis at federal financial regulators, modeled after the analysis required of executive branch federal agencies under executive orders (McCloskey and Peirce, 2014).
} 
both expanding the scope of regulation of institutions (improved disclosure, limits on leverage, liquidity requirements, governance standards) and a tighter regulation for markets and individual financial products.

Immediately in the aftermath of the crisis, the G-20 has called for a review of the scope of financial regulation, focusing on institutions, instruments and markets that are currently unregulated, along with ensuring that all systemically important institutions are appropriately regulated. This call reflects concern that the coverage of prudential regulation has been too narrow. Prudential regulation typically aims at minimizing the risk of failure by institutions (and settlement systems) that are viewed as critical to maintaining stability. Instruments of prudential regulation typically include minimum capital and liquidity requirements, supervisory inspection, mechanisms to requireearlyintervention by regulators, depositinsurance, and similar safety nets, as well as special insolvency and resolution mechanisms. The scale of relevant activities outside the regulatory perimeter depends on the definition of regulation. For the United States, it has been estimated that the total assets of the "shadow banking system" - i.e., bank-like entities not subject to bank-like prudential regulation - were roughly US $\$ 10$ trillion in late 2007, about the same size as those of the banking system. ${ }^{18}$ Indeed, the regulation of the shadow banking system has been one of the most active areas of regulatory reform efforts since the financial crisis. Despite some progress at strengthening the stability of the shadow banking system, progress to dates has been uneven (See e.g. Gorton and Metrick, 2010; Adrian and Ashcraft, 2012; Schwarcz, 2012; Adrian, Ashcraft, and Cetorelli, 2013). ${ }^{19}$

At the same time, macro-prudential regulation ought to incorporate thefact that systemic risk is an endogenous component of the global financial system; the seamless monitoring of the growing interconnectedness of its various institutional building blocks forms a central part of this new regulatory paradigm. Much like the CFPB, the new financial supervisory framework for the European Union, the European System of Financial Supervision (ESFS), which was adopted in 2011, rests on a micro- and a macro-prudential pillar and envisions the establishment of a single supervisory mechanism for banks led by the European Central Bank (Bini Smaghi, 2009; Véron, 2012).

Yet better regulation such as Dodd-Frank and new institutions such as the CFPB or the ESFS will not be enough; complementary adjustments to macroeconomic policy frameworks are equally essential. These adjustments would call for a more symmetric response to the build-up and unwinding of financial imbalances. The BIS, for example, sees a need to explore how to incorporate credit and asset price booms and the associated risk-taking more meaningfully in monetary policy frameworks (BIS, 2009, 2014). Likewise, additional consideration to the possible role of fiscal policy, including that of the tax system and fiscal balances, seem inevitable. Despite much progress on, much remains to be done. In its most recent annual report, the FSOC (2014) reports on a number of key milestones in financial reform implementation, including finalization of the Volcker Rule, bank capital rules, a supplementary leverage ratio for the largest banks and BHCs, enhanced prudential standards for the U.S. operations of large foreign banks, and the advent of clearing, trading, and registration requirements for swaps markets. Furthermore, policy development needs to be pushed forward with

\footnotetext{
${ }^{18}$ However, it is important to recognize that this total includes the assets of entities such as investment banks, which were subject to a degree of regulation, although this was often focused mainly on ensuring investor protection and appropriate business conduct (Carvajal, Dodd, Moore, Nier, Tower, and Zanforlin, 2009).

${ }^{19}$ In the context of shadow banking regulation, a key challenge is the potential for regulatory overlap when regulated banks actively participate in shadow financial system (Schwarcz,2012).
} 
proposed rule-makings on money market fund reform, risk retention for securitizations, and requirementsfor short-term liquidity coveragefor large banking organizations.

In addition to this long punch-list of regulatory efforts, a number of critical issues for financial stability remain yet to be included on that list. For example, Kane (2012) highlights theincentiveconflicts that led creditors and internal and externalsupervisors to short-cutand outsource due diligence. The Dodd-Frank strategy of reform does not adequately acknowledge or address these conflicts. Without reforms in the practical duties imposed on industry and governmental officials and in the way these issues of governance are enforced, financial safety nets will continue to expand and their expansion will undermine financial stability by generating large rewards for creative and aggressive risk-takers.

\section{References}

AdriAn, T., AND A. B. ASHCRAFT (2012): "Shadow Banking Regulation," Annual Review of Financial Economics, 4, 99-140.

Adrian, T., A. B. AshCraft, AND N. Cetorelli (2013): “Shadow Bank Monitoring,” in The Oxford Handbook of Banking, ed. by A. N. Berger, P. Molyneux, and J. O. S. Wilson. Oxford University Press, New York City, NY, 2nd edn.

ALFORD, D. (2006): “The Lamfalussy Process and EU Bank Regulation: Another Step on the Road to Pan-European Regulation?," Annual Review of Banking and Financial Law, 25(1), 389-435.

Anderson, C. D., D. R. CAPOzZA, AND R. van ORder (2011): “Deconstructing a Mortgage Meltdown: A Methodology for Decomposing Underwriting Quality," Journal of Money, Credit and Banking, 43(4), 609-631.

BAGEHOT, W. (1873): Lombard Street: A Description of the Money Markets. Scribner, Armstrong, New York, firstedn.

BARR, M. S. (2012): No Slack: The Financial Lives of Low-Income Americans. Brookings Institution Press, Washington, DC.

BARTH, J. R., T. LIY, AND W. LUY (2010): “Bank Regulation in the United States," CESifo Economic Studies, 56(1), 112-140.

BCBS (2013): International Regulatory Framework for Banks (Basel III) Basel Committee on Banking Supervision, Basel.

BEALES, H. (2012): "The Importance of Financial Literacy and the Financial Crisis and the CFPB," Presentation on "Reflections on the Federal Reserve and its Place in Today's Economy", George Washington University, Washington, DC.

BIERI, D. S. (2008): “The Basel Process, Financial Stability and the Age of Turbulence," Mimeograph, Virginia Tech, Blacksburg, VA.

(2009): "Financial Stability, the Basel Process and the New Geography of Regulation," Cambridge Journal of Regions, Economy and Society, 2(2), 303-331.

(2010): Lessons from the Financial Crisis: Causes, Consequences, and Our Economic Future chap. Regulation and Financial Stability in the Age of Turbulence, pp. 327-336. John Wiley \& Sons, Inc., Hoboken, NJ. 
Bini SMAGHI, L. (2009): "Going Forward: Regulation and Supervision after the Financial Turmoil," Research Paper Series No. 2009-47, Paolo Baffi Centre on Central Banking and Financial Regulation, Bocconi University, Milan.

BIS (2009): 79th Annual Report. Bank for International Settlements, Basel, Switzerland.

$$
\text { (2014): 84th Annual Report. Bank for International Settlements, Basel, Switzerland. }
$$

BLAGESCU, M., AND R. LLOYD (2006): “2006 Global Accountability Report,” Policy report, One World Trust, London.

BORDO, M. D., AND D. C. WHEELOCK (1998): “Price Stability and Financial Stability: The Historical Record," Federal Reserve Bank of St. Louis Review, 80(5), 41-62.

BORIO, C. E. V., AND M. DREHMANN (2009): “Towards an Operational Framework for Financial Stability: "Fuzzy" Measurement and its Consequences," Working Paper No. 265, Bank for InternationalSettlements, Basel.

CAlOMIRIS, C. W. (2000): U.S. Bank Regulation in HistoricalPerspective. Cambridge University Press, Cambridge, UK and New York.

CAlOMIRIS, C. W., AND G. GORTON (1991): Financial Markets and Financial Crises chap. The Origins of Banking Panics: Models, Facts, and Bank Regulation, pp. 109-174. University of Chicago Press, Chicago, IL.

Carvajal, A., R. DodD, M. Moore, E. Nier, I. TOWer, AND L. ZANForlin (2009): “The Perimeter of Financial Regulation," IMF Staff Position Note No. SPN/09/03, International Monetary Fund, Washington, DC.

CHANDLER, L. V. (1979): The Monetary-Financial System. Harper and Row Publishers, New York City, NY.

COPElAND, C. W. (2010): "Rulemaking Requirements and Authorities in the Dodd-Frank Wall Street Reform and Consumer Protection Act," CRSReportfor Congress No. R-41472, Congressional Research Service, Washington, DC.

(2013): “Economic Analysis and Independent Regulatory Agencies," White paper, Administrative Conference of the United States, Washington, DC.

FSOC (2014): 4th Annual Report. Financial Stability Oversight Council, Washington, DC.

GARRISON, A. F. (1987): “The Financial Institutions Regulatory and Interest Rate Control Act of 1978, Federal Banking, and the Judiciary: The Struggle to Define the Limitation of Cease and Desist Order Authority," Washington and Lee Law Review, 44(4), 1357-1379.

GeITHNER, T. (2014): Stress Test: Reflections on Financial Crises. Random House, New York.

GOODHART, C.A.E. (2008): “The Boundary Problem in Financial Regulation,” NationalInstitute Economic Review, 206(1), 48-55.

Gorton, G., AND A. MetricK (2010): “Regulating the Shadow Banking System,” Brookings Papers on Economic Activity, 41(2), 261-312.

HERRING, R. J. (2010): “How Financial Oversight Failed And What it May Portend for the Future of Regulation," Atlantic Economic Journal, 38(3), 265-282. 
JICKLING, M., AND E. V.MURPHY (2010): “Who Regulates Whom? An Overview of U.S. Financial Supervision," CRS Report for Congress No. R-40249, Congressional Research Service, Washington, DC.

KANE, E. J. (2007a): “Basel II: A Contracting Perspective,” JournalofFinancialServicesResearch, 32(1), 39-53.

(2007b): “Connecting NationalSafety Nets: The Dialectics of the Basel IIContracting Process," Atlantic Economic Journal, 35(2), 399-409.

264.

(2010): "Redefining and Containing Systemic Risk," Atlantic Economic Journal, 38(3), 251-

(2012): “Missing Elements in US Financial Reform: A Kübler-Ross Interpretation of the Inadequacy of the Dodd-Frank Act," Journal of Banking and Finance, 36(3), 654-661.

KEYS, B.J., A.SERU, AND V.VIG (2012): “LenderScreening and the Role ofSecuritization: Evidence from Prime and Subprime Mortgage Markets," Review of Financial Studies, 25(7), 2071-2108.

KRAINER, R.E.(2012): “'Regulating WallStreet:TheDodd-FrankActand theNew Architecture of Global Finance': A Review," Journal of Financial Stability, 8(2), 121-133.

(2013): “Towards a Program for Financial Stability," Journal of Economic Behavior \& Organization, 85(1), $207-218$.

KRULY, C. (2013): "Self-Funding and Agency Independence," George Washington University Law Review, 81(5), 1733-1754.

LUSARDI, A., AND O. S. MiTCHELL (2014): “The Economic Importance of Financial Literacy: Theory and Evidence," Journal of Economic Literature, 52(1), 5-44.

MAYeR, C., K. Pence, AND S. M.SHERlund (2009): “The Rise in Mortgage Defaults," Journalof Economic Perspectives, 23(1), 27-50.

MAYES, D., R. PRINGLE, AND M. TAYLOR (eds.) (2009): Towards a New Framework for Financial Stability. Central Banking Publications, London.

MCClOSKeY, A., AND H. PeIRCE (2014): “Holding Financial Regulators Accountable: A Case for Economic Analysis," Policy paper, American Enterprise Institute, Washington, DC.

MURPHY, E. V.(2013): “Who Regulates Whom and How? An Overview of U.S. Financial Regulatory Policy for Banking and Securities Markets," CRS Report for Congress No. R-43087, Congressional Research Service, Washington, DC.

ROBINSON, W. I. (2002): Historical Materialism and Globalizationchap. Capitalist Globalization and the Transnationalization of the State, pp. 210-229. Routledge.

SCHINASI, G. J. (2004): “Defining Financial Stability,” Working Paper No. 04/187, International Monetary Fund, Washington, DC.

SCHWARCZ, S. L. (2012): “Regulating Shadow Banking," Review of Banking and Financial Law, 31, 619-642.

STIGLER, G. J. (1971): “The Theory of Economic Regulation,” Bell Journal ofEconomics and Management Science, 2(1), 3-21. 
VÉRON, N. (2012): “Europe's Single Supervisory Mechanism and the Long Journey Towards Banking Union," Bruegel Policy Contribution, No. 2012/16, Bruegel and Peterson Institute for International Economics, Brussels.

VolKer, P. A., AND R. W. FERGUSON, JR (2008): “The Structure of Financial Supervision: Approaches and Challenges in a Global Marketplace," Report, Group of 30, Washington, DC.

WHITE, W.R. (2008): “PastFinancialCrises, theCurrentFinancial Turmoil, and the Need fora New MacrofinancialStability Framework," JournalofFinancial Stability, 4(4),307-312. 